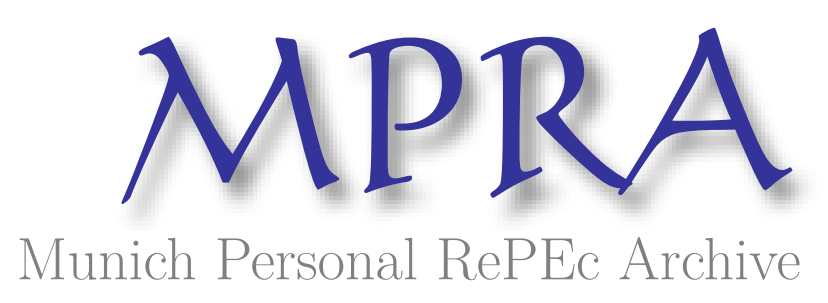

\title{
Outward Foreign Direct Investment from India
}

Saikia, Dilip

Centre for Development Studies, Trivandrum, Kerala

March 2009

Online at https://mpra.ub.uni-muenchen.de/29079/

MPRA Paper No. 29079, posted 28 Feb 2011 15:37 UTC 


\title{
OUTWARD Foreign DireCt INVESTMENT From INDIA*
}

\author{
DILIP SAIKIA \\ CENTER FOR DEVELOPMENT STUDIES \\ TRIVANDRUM, KERALA \\ Email: dilip.gu@gmail.com
}

\begin{abstract}
India has been continually attracting massive foreign investments since the opening up of its economy with a series of liberalization policies in the early 1990s. This inward FDI plays an important role in the Indian economy as a financier of her BOP. However in recent years, India has been fast emerging as an exporter of large foreign direct investment. An increasing number of Indian firms are resorting to outward investment in order to access new technologies, skills and managerial expertise etc. from the developed countries. This is a bit of an anomaly. What explains this boom in FDI from India? What have been the motivations to invest abroad? What could be its economic implications? These are the questions that generally come into mind. A large number of strategic factors and motivations along with a series of policies liberalization and financial deregulation those are undertaken since the early 1990s are supposed to be the driving forces for this outflow of FDI from India. The present article tries to address some of these issues.
\end{abstract}

Key Words: Outward Foreign Direct Investment, Balance of Payment, Capital Account JEL Classification: F21, F23, F32, F36

First Draft: March, 2009

\footnotetext{
* The paper is a part of the course on Issues in Indian Agriculture during my M. Phil course (2008-2010) at the Centre for Development Studies, Trivandrum.
} 


\section{OUTWARD FOREIGN DIRECT INVESTMENT FROM INDIA}

\section{INTRODUCTION}

While India has been continually attracting massive foreign investments from the world's major investor's since1991, in recent years it has been fast emerging as an exporter of large foreign direct investment (FDI). An increasing number of Indian firms are resorting to outward investment in order to access new technologies, skills, and managerial expertise etc. from developed countries. This is an apparent anomaly in the sense that while as a developing country with scarce capital resources and low foreign reserves the country has to depend largely on the inward FDI to finance her BOP, but at the same time it has become an exporter of scarce capital to the world capital market. Here, the question naturally arises that what explains this boom in FDI from India? What have been the motivations of Indian company's strategies to invest abroad? What could be the implications of this outward FDI on the economy? A large number of strategic factors and motivations along with a series of policy liberalization and financial deregulation that are started since the early 1990s are supposed to be the driving forces for this outflow of FDI from India. The present article tries to address some of these issues.

The paper is organized into 4 sections. Section 2 analyses the importance of inward FDI from the Balance of Payments perspectives. Section 3 provides a profile of the outward FDI and also examines the motives and strategic factors that explain the OFDI from India. Section 4 sums up our discussion.

\section{INFLOWS OF FDI TO INDIA AND ITS IMPORTANCE}

India has been continually attracting massive foreign investments from the world's major investor's since the opening up of its economy with a series of liberalization policies since 1991. Moreover, a number of measures during 1998 and 1999 designed to encourage inward FDI has boosted the inflow of FDI to India in the recent years. High rate of economic growth, deregulation, liberal investment rules and operational flexibility further result in increase the inflow of FDI to India. The inflow of foreign investment (Foreign Direct Investment plus Foreign Portfolio Investment), given in the following table shows that there has been a rapid expansion in the inward FDI since the early2000s. The magnitude inward FDI to India has increased from US\$ 97 million in 1990-91 to US\$ 4 billion in 2000-01 and then to US\$ 34.3 
billion in 2007-08. As per the recent RBI report (January, 2009) the inward FDI to India in the first two quarters of the financial year 2008-09 recorded at US\$21.4 billion.

\begin{tabular}{|c|c|c|c|}
\hline \multicolumn{3}{|c|}{ Table 1: Foreign Investment Inflows to India (US \$ million) } \\
\hline \multirow{2}{*}{ Year } & $\begin{array}{c}\text { Direct } \\
\text { Investment }\end{array}$ & $\begin{array}{c}\text { Portfolio } \\
\text { Investment }\end{array}$ & $\begin{array}{c}\text { Total Foreign } \\
\text { Investment }\end{array}$ \\
\cline { 2 - 4 } & $\mathbf{( A )}$ & $\mathbf{( B )}$ & $\mathbf{( A + B )}$ \\
\hline $1990-91$ & 97 & 6 & 103 \\
\hline $1991-92$ & 129 & 4 & 133 \\
\hline $1992-93$ & 315 & 244 & 559 \\
\hline $1993-94$ & 586 & 3567 & 4153 \\
\hline $1994-95$ & 1,314 & 3,824 & 5,138 \\
\hline $1995-96$ & 2144 & 2748 & 4892 \\
\hline $1996-97$ & 2,821 & 3,312 & 6,133 \\
\hline $1997-98$ & 3,557 & 1,828 & 5,385 \\
\hline $1998-99$ & 2,462 & -61 & 2,401 \\
\hline $1999-00$ & 2,155 & 3,026 & 5,181 \\
\hline $2000-01$ & 4,029 & 2,760 & 6,789 \\
\hline $2001-02$ & 6,130 & 2,021 & 8,151 \\
\hline $2002-03$ & 5,035 & 979 & 6,014 \\
\hline $2003-04$ & 4,322 & 11,377 & 15,699 \\
\hline $2004-05$ & 6,051 & 9,315 & 15,366 \\
\hline $2005-06$ & 8,961 & 12,492 & 21,453 \\
\hline $2006-07$ & 22,826 & 7,003 & 29,829 \\
\hline $2007-08(\mathrm{P})$ & 34,362 & 29,395 & 63,757 \\
\hline
\end{tabular}

Note: P- Preliminary

Source: RBI Bulletin, various issues

The inward FDI has played an important role in the development of the Indian economy. It has enabled India to achieve a significant growth and development with a certain degree of financial stability. The importance of the inward FDI in the Indian economy can be seen as the financier of the BOP of the country. The trade balances for India has been negative for the last more than one and half decade and as table 2 shows that except for the three years period between 2001 and 2004 the current account balance is in deficit. So, given the fact that the current account has always been in deficit, it is the inflows in capital account that keeps the overall BOP of the country surplus (except for the three years 1990-91, 199293 and 1995-96 in which the overall BOP is deficit). In the capital account, the major component with positive net contribution is foreign investment (FDI and foreign portfolio investment) and in foreign investment FDI is the most important contributor to the capital account, as the portfolio investment is highly volatile and speculative. It is the fortune of the country that she has been attracting a large amount of FDI that finances the overall BOP. 


\begin{tabular}{|c|c|c|c|c|c|c|}
\hline \multirow{2}{*}{ Year } & \multirow{2}{*}{ Net FDI* } & \multicolumn{2}{c|}{ Balance of Payments } & \multicolumn{2}{c|}{ Percentage of FDI to- } \\
\cline { 3 - 7 } & & $\begin{array}{c}\text { Current a/c } \\
\text { Balance* }\end{array}$ & $\begin{array}{c}\text { Capital a/c } \\
\text { Balance* }\end{array}$ & $\begin{array}{c}\text { Overall } \\
\text { BPO* }\end{array}$ & $\begin{array}{c}\text { Capital a/c } \\
\text { balance }\end{array}$ & $\begin{array}{c}\text { Overall } \\
\text { BOP }\end{array}$ \\
\hline $1990-91$ & 97 & -9680 & 7056 & -2492 & 1.37 & -3.89 \\
\hline $1991-92$ & 129 & -1178 & 3910 & 2599 & 3.30 & 4.96 \\
\hline $1992-93$ & 315 & -3526 & 3876 & -590 & 8.13 & -53.39 \\
\hline $1993-94$ & 586 & -1158 & 8895 & 8537 & 6.59 & 6.86 \\
\hline $1994-95$ & 1,314 & -3369 & 8502 & 5787 & 15.46 & 22.71 \\
\hline $1995-96$ & 2144 & -5910 & 4089 & -1221 & 52.43 & -175.59 \\
\hline $1996-97$ & 2,821 & -4619 & 12006 & 6793 & 23.50 & 41.53 \\
\hline $1997-98$ & 3,557 & -5500 & 9844 & 4511 & 36.13 & 78.85 \\
\hline $1998-99$ & 2,462 & -4038 & 8435 & 4222 & 29.19 & 58.31 \\
\hline $1999-00$ & 2,155 & -4698 & 10444 & 6402 & 20.63 & 33.66 \\
\hline $2000-01$ & 4,029 & -2666 & 8840 & 5868 & 45.58 & 68.66 \\
\hline $2001-02$ & 6,130 & 3400 & 8551 & 11757 & 71.69 & 52.14 \\
\hline $2002-03$ & 5,035 & 6345 & 10840 & 16985 & 46.45 & 29.64 \\
\hline $2003-04$ & 4,322 & 14083 & 16736 & 31421 & 25.82 & 13.76 \\
\hline $2004-05$ & 6,051 & -2470 & 28022 & 26159 & 21.59 & 23.13 \\
\hline $2005-06$ & 8,961 & -9902 & 25470 & 15052 & 35.18 & 59.53 \\
\hline $2006-07$ & 22,826 & -9565 & 45203 & 36606 & 50.50 & 62.36 \\
\hline $2007-08$ & 34,362 & -17034 & 107993 & 92164 & 31.82 & 37.28 \\
\hline \multirow{2nyyyyy}{*}{} & & & & & &
\end{tabular}

Note: * figures in US \$ million

Source: RBI, Database on Indian Economy

As the above table shows that the inward FDI constitutes a significant share of the current account (shown in column 6) as well as the overall BOP (shown in column 7). In fact for some years (e.g. 1997-98, 200-01 \& 2006-07) the share of the inward FDI to the overall BOP is more than two third and for the year 1995-96 the share is more than 150 percent. However, even the country depends on the inward FDI to finance its BOP; in recent years it has become an exporter of capital, which is a bit of an apparent anomaly. This issue will consider in the next section.

\section{OUTWARD FDI (OFDI) FROM INDIA ${ }^{1}$}

\subsection{Size and Growth of OFDI}

Although the outward FDI from India has rapidly increased in the recent years, investment by Indian companies abroad is not a new phenomenon and the foundation was laid a long time

\footnotetext{
${ }^{1}$ Here we consider only the outward FDI from India. We will not consider the outward foreign portfolio investment because as it is obvious from the Table 3 that the magnitude of outward foreign portfolio investment from India is very small.
} 
ago (Morris, 1987 \& 1990; Nagaraj, 2008 \& Nayyar, 2008). Investments made by some Indian companies during the British rule in physical assets and raw material processing facilities in countries that were under the British colonial rule is seen in the literature (Morris, 1987). In fact, the first foreign investment abroad by an Indian firm took place with the establishment of a textile mill in Ethiopia by Birlas in 1955. During the 1960s a number of foreign investments were undertaken in Kenya, Uganda, Nigeria, Malaysia, Thailand and Ceylon (Morris, 1987). ${ }^{2}$

Even the Indian companies have been investing abroad since early 1970s; the magnitudes and number of OFDI were quite small until mid 1990s and has expanded rapidly since 2000 (Kumar, 2008; Nayyar, 2008 \& Pradhan, 2008). The growth of OFDI from India can be divided into two phases: the First Wave (1970s to 1990) and the Second Wave (1991 onwards). Morris (1987) has provided a detail account of the trends of Indian OFDI for the period 1950-1982. The outward FDI activities in the first wave (FW) were very low (see Table 3) and confined to a group of large family owned firms like Birla, Tata, Kirloskar, Thapar, Mafatlal, Singhania, Mahindra, etc. (Pradhan, 2008). Moreover, most of these investments were in the form of minority joint ventures (Morris, 1990) and they were largely concentrated in the developing countries. ${ }^{3}$ The main factors those were responsible for the low volume of OFDI in the FW, as Pradhan (2008) observes can be the restrictive government (regulatory and approval) policies with respect to the OFDI, the low level of exports by the Indian firms and so forth.

In comparison to the first wave, there has been a rapid expansion of OFDI from India during the 1990s and it has registered a phenomenon increase and structural change in the early 2000s (Nayyar, 2008 \& Pradhan, 2008) and then jumped to a new height since 2005. The stock of OFDI from India increased from \$124 million in 1990 to US\$ 9569 million in $2005 .{ }^{4}$ Further undergoing a structural change, the OFDI has jumped to US\$ 15.04 billion in 2006-07 from US\$ 5.8 billion in 2005 and then further \$18.8 billion in 2007-08 (Table 4). In the first two quarters of 2008-09 the amount of total proposal clears record at $\$ 8.9$ billion, as against the actual investment of $\$ 5.7$ billion $^{5}$. Unlike the $\mathrm{FW}$, the Indian companies have

\footnotetext{
${ }^{2}$ Most of these investments were made by Birlas.

${ }^{3}$ Developing countries constitute about $90 \%$ of the India's OFDI in 1976, which further increased up to $96 \%$ in 1986. Countries like Malaysia, Thailand, Kenya, Indonesia, Singapore, and Nigeria were the most preferred destinations for Indian OFDI abroad (Pradhan 2008).

${ }^{4}$ Nayyar, 2008: 113

${ }^{5}$ RBI Monthly Bulletin, January 2009
} 
gone for control over their investment abroad in the second wave and most of these investments has directed to the developed industrialized countries. ${ }^{6}$

\begin{tabular}{|c|c|c|c|c|}
\hline \multicolumn{5}{|c|}{ Table 3: Indian OFDI Stock (\$ million), 1976 to 2006} \\
\hline \multirow[t]{2}{*}{ Waves } & \multirow[t]{2}{*}{ Year } & \multirow{2}{*}{$\begin{array}{l}\text { Number of } \\
\text { Approvals }\end{array}$} & \multicolumn{2}{|c|}{ Value of OFDI stock (\$ millions) } \\
\hline & & & Approved & Actual \\
\hline \multirow{3}{*}{$\begin{array}{c}\text { First Wave } \\
\text { (1970s to 1991) }\end{array}$} & As on 1-1-1976 & 133 & 38 & 17 \\
\hline & As on $31-8-1980$ & 204 & 119 & 46 \\
\hline & As on $1-9-1986$ & 208 & 90 & 75 \\
\hline \multirow{4}{*}{$\begin{array}{l}\text { Second Weave } \\
\text { (1991 onwards) }\end{array}$} & As on 31-12-1990 & 214 & NA & NA \\
\hline & As on 31-12-1995 & 1016 & 961 & 212 \\
\hline & As on $31-3-2000$ & 2204 & 4151 & 794 \\
\hline & As on $28-2-2006$ & 8620 & 16395 & 8181 \\
\hline
\end{tabular}

Source: Pradhan, 2008, p. 4

\begin{tabular}{|l|c|c|c|c|c|c|}
\hline \multicolumn{7}{|c|}{ Table 4: India's Foreign Investment Abroad } \\
\hline \multirow{2}{*}{ Year } & \multicolumn{2}{|c|}{ Foreign Direct Investment } & \multicolumn{2}{c|}{ Foreign Portfolio Investment } \\
\cline { 2 - 7 } & $\begin{array}{c}\text { CREDIT } \\
\text { (US \$ } \\
\text { million) }\end{array}$ & $\begin{array}{c}\text { DEBIT } \\
\text { (US \$ } \\
\text { million) }\end{array}$ & $\begin{array}{c}\text { NET } \\
\text { (US \$ } \\
\text { million) }\end{array}$ & $\begin{array}{c}\text { CREDIT } \\
\text { (US \$ } \\
\text { million) }\end{array}$ & $\begin{array}{c}\text { DEBIT } \\
\text { (US \$ } \\
\text { million) }\end{array}$ & $\begin{array}{c}\text { NET } \\
\text { (US \$ } \\
\text { million) }\end{array}$ \\
\hline $2000-01$ & 70 & 829 & -759 & 0 & 170 & -170 \\
\hline $2001-02$ & 99 & 1490 & -1391 & 0 & 69 & -69 \\
\hline $2002-03$ & 73 & 1892 & -1819 & 0 & 35 & -35 \\
\hline $2003-04$ & 142 & 2076 & -1934 & - & - & - \\
\hline $2004-05$ & 35 & 2309 & -2274 & 0 & 24 & -24 \\
\hline $2005-06$ & 216 & 6083 & -5867 & 0 & 0 & 0 \\
\hline $2006-07$ & 764 & 15810 & -15046 & 86 & 30 & 56 \\
\hline $2007-08$ & 2477 & 21312 & -18835 & 236 & 74 & 162 \\
\hline
\end{tabular}

Source: RBI Database on Indian Economy

Most of this expansion in the outward FDI has led by mergers and acquisitions abroad by Indian firms (Nayyar, 2008). The takeover of Corus - an Anglo-Dutch company by Tata Steel's, Tata Motor's takeover of Jaguar and Land Rover, Videocon Industries acquiring Daewoo's electronics manufacturing facility in South Korea, Tata Chemicals Limited's takeover of U.S. soda-ash producer General Chemicals Industrial Products, Wipro Technologies takeover of Infocrossing are the major acquisition abroad by Indian companies. Between 1991 and 2003 the number Indian parents companies abroad have increased from

\footnotetext{
${ }^{6}$ About $75 \%$ of the outward FDI from India was in the industrialized countries in the early 2000s (Nayyar, 2008). This increasing attractiveness of developed countries to Indian OFDI is due to the growing sophistication of ownership advantages of Indian manufacturing firms and emergence of service firms like software companies catering to the demand of the developed countries (Pradhan, 2008).
} 
187 to 1700 , by phenomenal rate of $809 \%^{7}$. The ownership of mergers and acquisitions by Indian companies between 2000 and 2005 are given Table 5.

\begin{tabular}{|c|c|c|c|c|c|}
\hline \multicolumn{7}{|c|}{ Table 5: Some Statistics of Foreign Direct Investment of India, 2000-05 } \\
\hline \multirow{2}{*}{ Year } & FDI to and from India* & $\begin{array}{c}\text { Stack of outstanding } \\
\text { OFDI** }\end{array}$ & Mergers \& acquisitions* \\
\cline { 5 - 6 } & Inward & Outward & & Sales & Purchase \\
\hline $2000-01$ & 1910 & 709 & 2.6 & 1219 & 910 \\
\hline $2001-02$ & 2988 & 981 & 4.0 & 1037 & 2195 \\
\hline $2002-03$ & 1658 & 1798 & 5.8 & 1698 & 270 \\
\hline $2003-04$ & 1462 & 1494 & 7.8 & 949 & 1362 \\
\hline $2004-05$ & 2320 & 1647 & 10.1 & 1760 & 863 \\
\hline $2005-06$ & 3358 & 2679 & 12.1 & 4210 & 2659 \\
\hline Total & $\mathbf{1 3 6 9 6}$ & $\mathbf{9 3 0 8}$ & - & $\mathbf{1 0 8 7 3}$ & $\mathbf{8 2 4 9}$ \\
\hline
\end{tabular}

Note: * Figures in US \$ million,

** Figures in US \$ billion and for calendar year

Source: Nayyar, 2008, pp. 114-116

\subsection{Motives and Factors Driving the OFDI}

The OFDI from India in the first wave was largely motivated by the government policies such as the Monopolies and Restrictive Trade Practices Act (MRTP), Foreign Exchange Regulation Act etc. and the 'south-south' cooperation which has given a liberal approach to the developing country OFDI (Pradhan, 2008) and it was, further, replaced by the motives like develop trade-supporting networks abroad, exploit ownership advantages in efficient manner, increase the scale of production across regions, acquire additional technologies, skills, management expertise, marketing distribution networks overseas ect, and secure natural resources like natural gas and petroleum in the second wave (Pradhan, 2008 \& Nayyar, 2008). That is the motivation of the outward FDI from India, which was the 'southsouth' cooperation in the earlier period, was replaced by the cause of global competitiveness of Indian firms in the later period (Pradhan, 2008).

Nagaraj (2006) classifies the factors that drive the process of OFDI from India into domestic and international factors (policy reforms) and industry specific factors, whereas Nayyar (2008) has mentioned about the underlying factors (industry and sector specific) and enabling factors (policy and institutional changes). Whatever the classification of these factors the fact is that since 1990, an increasing number of Indian firms are resorting to outward investment in order to access high growth markets for its products, acquire high skill

\footnotetext{
${ }^{7}$ This growth rate is higher than that of for the countries like China (805\%), Republic of Korea (611\%), Brazil (116\%) and Hong Kong (90\%) over approximately comparable period. (Nayyar, 2008 and Pradhan, 2008)
} 
technology, knowledge, management expertise ect, sourcing raw materials, capturing international brand names, boost their positioning in the value chain, attaining economies of scale and size and global leadership aspirations (Pradhan, 2008; Nayyar, 2008 and Nagaraj, 2006). ${ }^{8}$ This is clear from the fact that about $60 \%$ of the outward FDI from India are in the manufacturing sector and $23 \%$ in the information technology related sectors during 20002005 and more than two third of these investments were resorting in the developed industrialized countries.

However, these factors are guided by a series of policy liberalization towards OFDI and institutional changes. The evolution of Indian policy regime towards the OFDI can be categorized into three phases: 1969-92, 1992-2003 and 2004 onwards. ${ }^{9}$ The first phase that was started with the formulation of General Guidelines on Indian joint ventures overseas in 1969 was characterized by restrictive policies. The basic features of the first phase was- only industrial ventures, investments only in the form of minority-owned joint ventures, no cash remittances were allowed, only capitalized exports for equity, only capital goods and technology as a means of financing equity etc. The second phase (1992-2003), which can be termed as permissive, was started with the introduction of automatic route for overseas investments up to $\$ 2$ million. The basic features of the second phase was - allowed cash remittances for investment, removal of minority ownership restrictions, single window created in the Reserve Bank of India in 1995 and increased the limit of automatic approval to $\$ 4$ million, which further increased to $\$ 50$ million with the introduction of Foreign Exchange Management Act (FEMA) in 2000 and to $\$ 100$ million in 2002. The third phase (2004 onwards) started with allowing the firms to invest up to $100 \%$ of their net worth under automatic route in 2004. This limit further increased to $200 \%$ of net worth in 2005 , then $300 \%$ of net worth in 2007 and finally to $400 \%$ of net worth in 2008 . These liberalization policies towards OFDI combined with the financial deregulation, which started in the early 1990s, gathered momentum and by the early 2000s provided Indian firms with significant enlarged access to domestic capital markets (Nayyar, 2008) and thus results in rapid expansion in the outward FDI and acquisition abroad.

\footnotetext{
${ }^{8}$ These are the underlying factors as described by Nayyar (2008). A global survey carried out by UNCTAD revealed that market access was the most significant motive for $51 \%$ of the respondents, followed by efficiency seeking (22\%), resource-seeking (13\%) and created-asset-seeking (14\%). (UNCTAD, 2006; cited in Nayyar, 2008: 124)

9 Pradhan (2008) has classified the Indian policy regime towards OFDI into two phases: 1969-1992 and 1992 onwards, whereas Nayyar (2008) has classified the policy regime into three phases: restrictive policy (1978-92), permissive policy (1992-2003), and liberal policy (2003 onwards).
} 


\subsection{Implications of OFDI}

The large scale of outward FDI from India has both the positive and negative impacts at both the micro level of firms and macro level for the country. ${ }^{10}$ At the micro level negative impacts on firms are increased costs, lower profits, higher debt and overstretched finances, etc. However, these negative impacts are outweighed by the positive impacts such as, enlarged market access for exports, possibilities of realizing scale economies through horizontal or vertical integration, upgrading, assimilating and developing technology, acquiring international brand names etc. At the macro level there are the benefits like market access for exports, scale economies in production, technology acquisition and upgrading, sourcing inputs or raw materials etc., as against the negative effects of increase external pressure due to the huge debt abroad ${ }^{11}$, lose of scarce financial resources which have alternative use at home etc. From the BOP perspectives, although the outward FDI results in capital outflows in the short run, there is inflow of dividends, royalties or fees in the long run and if these investments are financed by borrowing abroad, then there would also be outflows of investment income (in the form of interest payments) in subsequent years (Nayyar, 2008). On the whole, the BOP effects may be negative in the short run but should be positive in the medium term or long term.

\section{Conclusion}

The paper examines the motives and strategic factors behind the large scale of outward FDI from India in the recent years. In the process we have explained the size and importance of the inward FDI to India from the BOP perspectives and also the size and trends of the OFDI from India. We have seen that although Indian companies have been investing abroad since the early 1970s, its magnitude was very small until the mid 1990s and has expand rapidly since the early 2000s and then jumped to a new height since 2005. These OFDI has been motivated by a large number of strategic factors such as access high growth markets, acquire high skill technology, knowledge, management expertise ect, sourcing raw materials, develop trade-supporting networks abroad, exploit ownership advantages in efficient manner, increase

\footnotetext{
${ }^{10}$ Nayyar (2008) has also mentioned about meso level implications for industries or sectors, such as upgrading the process, upgrading the product, moving up the value chain or moving on to a new value chain on the positive side and failure of materialize such benefits on the negative side.

${ }^{11}$ Nagaraj (2006) observed that many of the recent large accusations are predominantly financed by debt finance raised from global capital markets. He further observed that the boom in the outward movements is likely to increase external pressure on India to quickly reduce tariffs and dismantle the remaining restrictions on capital inflows (Nagaraj, 2006: 4718).
} 
the scale of production across regions, capturing international brand names, boost their positioning in the value chain, attaining economies of scale and size and so on, along with a series of policy liberalization covering OFDI and financial deregulation which started in the early 1990s. But at the same time we must keep it mind that this rapid expansion of OFDI also implies the capacity and ability of the Indian investors/firms has increased over the years to compete in the world market. As Pradhan (2008) has observed, "The globalization process has speeded up in recent years the desire of Indian firms to exploit these advantages in the global markets." Considering the implications of OFDI on the economy, we have seen that the outward FDI has both the positive and negative impacts at the micro level of firms as well as at the macro level for the country. From the BOP side, although outward FDI results in outflows of scarce capital resources from the country in the short run, there is inflow of dividends, royalties or fees etc. in the long run along with new technologies, skills, and managerial expertise and so on.

Thus, we can conclude that the motivation of the outward FDI from India, which was the 'south-south' cooperation in the earlier period, was replaced by the cause of global competitiveness of Indian firms in the recent period. The Indian investors/firms learn the skills and acquire the capacity and ability over the years and started to invest abroad as a strategy of acquiring new technologies, skills and expertise from developed countries. These benefits from investments abroad may not be visible in the short run, but there will be substantial benefits with positive impacts on India's global competitiveness in the long run.

\section{REFERENCES}

Balasubramanyam, V. N. and David Sapsford (2007) "Does India Need a Lot More FDI?", Economic and Political Weekly, April 28, pp. $1549-1555$

Chandra, N. K. (1973) "Western Imperialism and India Today-I", Economic and Political Weekly, Vol. 8, No. 4/6, pp. 221- 244

Kumar, Nagesh (2008) "Internationalization of Indian Enterprises: Patterns, Strategies, Ownership Advantages and Implications", RIS Discussion Papers, No 140, Research and Information System for Developing Countries, New Delhi, pp1-27

Morris, Sebastian (1987) “Trends in Foreign Direct Investment from India (1950-1982)", Economic and Political Weekly, Vol. 22, No. 45-46, November 7 \& 14, pp 1909-18 and pp 1963-69 
Morris, Sebastian (1990) "Foreign Direct Investment from India: Ownership and Control of 'Joint Ventures' Abroad”, Economic and Political Weekly, Vol. 25, No. 7/8, pp. M23M34

Nagaraj, R (2006) “Indian Investments Abroad”, Economic and Political Weekly, November 18, 2006, pp 4716-4718

Nayyar, Deepak (2008) "The Internationalization of Firms from India: Investment, Mergers and Acquisitions" Oxford Development Studies, Vol. 36, No. 1, pp 111- 131.

Pradhan, J.P. and V. Abraham (2005) "Overseas Mergers and Acquisitions by Indian Enterprises: Patterns and Motivations", Indian Journal of Economics, Vol. LXXXV, pp. 365-386.

Pradhan, Jaya Prakash (2007) "Growth of Indian Multinationals in the World Economy: Implications for Development" ISID Working Paper, No. 2007/04, Institute for Studies in Industrial Development, New Delhi

RBI (2008) Monthly Bulletin, January, Reserve Bank of India, Mumbai, pp 1797-1802

Sen, Pronab (1995) "Foreign Direct Investment: A Solution to BOP Problems?", Economic and Political Weekly, Vol. 30, No. 30, pp. 1921-1927

Srivastava, Sadhana (2003) "What Is the True Level of FDI Flows to India?" Economic and Political Weekly, February 15, pp. 608-610. 